\title{
BILATERAL ACCESSORY BREAST TISSUE PRESENTING AS MASS IN AXILLA WITH LEAKING MILK
}

Vineet Chaturvedi ${ }^{1}$, Seema Dayal ${ }^{2}$

\section{HOW TO CITE THIS ARTICLE:}

Vineet Chaturvedi, Seema Dayal. "Bilateral Accessory Breast Tissue Presenting as Mass in Axilla with Leaking Milk". Journal of Evolution of Medical and Dental Sciences 2014; Vol. 3, Issue 60, November 10;

Page: 13481-13483, DOI: 10.14260/jemds/2014/3798

ABSTRACT: Accessory breasts are an uncommon entity. They may present as asymptomatic masses or cause symptoms such as pain or restriction of arm movements even some time milk leaks from accessory breast. It may prove to be diagnostic challenge if found in locations along or outside the mammary line. We report a very rare case of an ectopic bilateral accessory breast presenting as mass in axilla with leaking milk in lactating young female. FNAC was diagnostic tool.

KEYWORDS: Accessory breast, FNAC, Lactation.

CASE REPORT: A thirty years old Asian Nepali female presented with bilateral axillary swelling with leaking milk from swelling since one year. It had appeared during the first trimester of her third pregnancy but remained static in size and increased in size during lactation period. Her third child at the time of presentation was three month old.

Examination revealed bilateral axillary swelling with leaking milk. Swelling was $3 \times 2 \mathrm{cms}$ in size on both sides that was soft, mobile and free from underlying tissue. Clinically a diagnosis of bilateral accessory breast was arrived at with an intent to rule out other pathologies of the normal breast.

FNAC was diagnostic tool. Cytological examination showed acini composed of cubodial cell with round uniform, vesicular nucleus and vacuolated cytoplasm. Myoepithelial cells are recognized a small, spindly dark homogenous bipolar nuclei with very scant cytoplasm.

Biochemical examination of fluid conformed milk.

DISCUSSION: Accessory breast occur in $0.4-6 \%$ of women ${ }^{1}$.They may present as asymptomatic mass or cause pain, restriction of arm movement, cosmetic problems or anxiety. Commonly accessory breasts are bilateral ${ }^{2}$.The ectodermal ridge like thickening from which breast develop, normally extend from anterior limb bud to the posterior limb bud along either side of the ventral surface of the fetus.

Most of the ridge undergoes regression except on the anterior thorax where breast develop. If this regression does not occur and ridge persist, supernumerary nipples or breasts develop along milk line. Thus, breast tissue may be found along the anterior trunk, superior or inferior to the main breast, right up to the inguinal areas and occasionally into the vulva.,34

Accessory breast tissue usually becomes noticeable after hormonal stimulation usually after puberty, pregnancy or lactation. ${ }^{5}$ They can undergo monthly premenstrual changes such as tenderness, swelling and irritation from clothes. It may also be diagnostic challenge as other benign and malignant lesions occurs in this area. Indeed, there have been reports of fibroadenoma ${ }^{6}$ and even cancer developing in the accessory breasts. 7,8 


\section{CASE REPORT}

FNAC is always a useful diagnostic tool.5,9 Fnac of the bilateral axillary swelling showed acini and sheets of ductal epithelial cells composed of cubodial cells that line the lumen of glands. The nucleus of ductal cells was round uniform, vesicular and cytoplasm was showing vacoulations.

An interrupted layer of myoepithelial cells surround glandular cells in milk background was also seen.

Biochemical examination of fluid conformed milk.

CONCLUSION: Bilateral acessory axillary breasts with lactation changes is very rare condition. But this entity must be kept in mind while dealing with swelling in the axilla especially in pregnant or lactating female. FNAC is a diagnostic tool which is required for conformation of diagnosis followed by treatment of accessory axillary breast tissue.

\section{REFERENCES:}

1. Down s, Barr L, Baildam AD, Bunderd N. Managment of accessory breast tissue in the axilla. Br J surg, 2003; 90 (10): 213-4.

2. Dalal S, Nityasha, Dahiya R, Kant K. spontaneous milk fistula from an accessory breast, An annoy complication. The internet Journal of surgery 2009;18.

3. Mandal Ak, Chaudhary S. Tuberculosis. Textbook of pathology 1st ed Avichal publication. New Delhi, 2010; 658.

4. Lesavoy MA, Gomez -Garcia A, Nejol R etal. Axillary breast tissue, clinical presentation and surgical treatment. Ann plast surg 1995; 35 (4); 356-60.

5. Solanki R, Choksi D, Duttary D. Accesory breast tissue presenting as a large pendulous mass in the axilla: a diagnostic dilemma. Journal of the New Zealand Medical Association 04 July, 2008, 121(1277).

6. Conde DM, Torressan RZ, Kashimoto E etal. Fibroadenoma in axillary supernumerary breast: case report. Sao Paulo med J, 2005, 123 (5): 253- 5.

7. Marko populous C, Kouskos E, Kontzoglou K etal. Breast cancer in ectopic breast tissue.Eur J Gynaecol oncol, 2001; 22 (2): 157-9.

8. Evans DM, Guyton DP. Carcinoma of the axillary breast. J surg oncol 1995: 59: 190 -195.

9. Das DK, Gupta SK, Methew SV etal. Fine needle aspiration cytologic diagnosis of axillary accessory breast tissue, including its physiologic and pathologic lesions, Acta cytol 1994: 38: 130-135. 

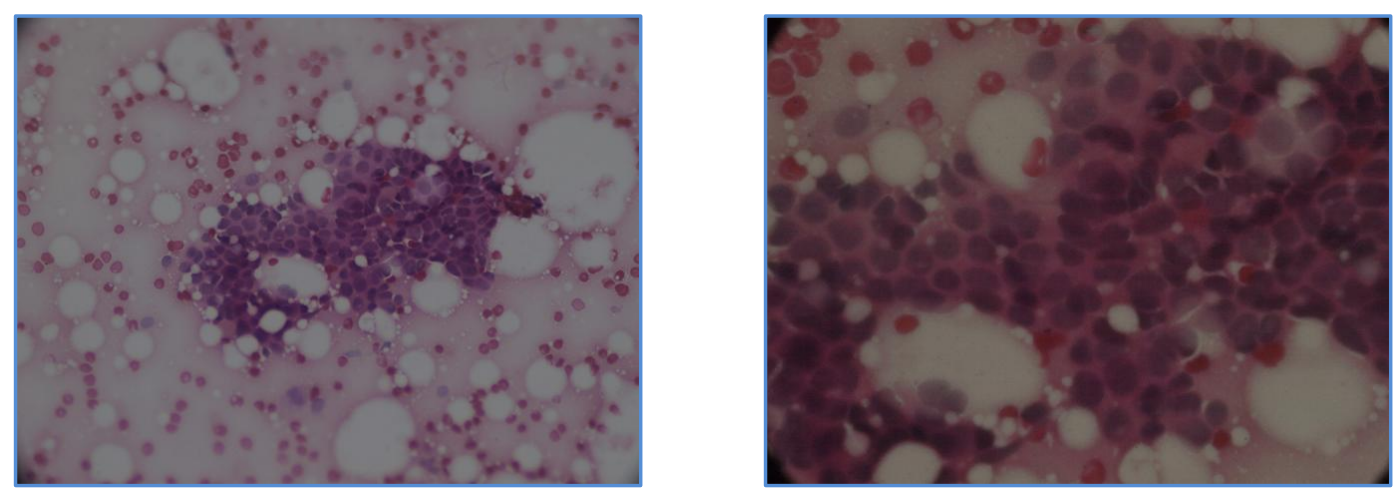

Microscopic photographs of FNA smears showing benign breast acinar cells (H\&E 10 x, 40x).

\section{AUTHORS:}

1. Vineet Chaturvedi

2. Seema Dayal

\section{PARTICULARS OF CONTRIBUTORS:}

1. Assistant Professor, Department of Pathology, RIMS \& R, Safai, Etawah.

2. Associate Professor, Department of Pathology, RIMS \& R, Safai, Etawah.

\section{NAME ADDRESS EMAIL ID OF THE} CORRESPONDING AUTHOR:

Dr. Vineet Chaturvedi, Assistant Professor, Department of Pathology, RIMS \& R, Safai, Etawah.

Email: vinch555@yahoo.in seemadayal77@rediffmail.com

Date of Submission: 10/10/2014. Date of Peer Review: 11/10/2014. Date of Acceptance: 06/11/2014. Date of Publishing: 10/11/2014. 